Jurnal Poetika Vol. IV No. 2, Desember 2016

\title{
KERINDUAN PADA YANG REAL DALAM NOVEL Akar KARYA DEE
}

\author{
Fina Hiasa \\ Prodi Pendidikan Bahasa dan Sastra Indonesia, Universitas Bengkulu \\ finahiasa@yahoo.com
}

\begin{abstract}
Abstrak
Penelitian ini bertujuan untuk mengungkapkan bagaimana hasrat pengarang termanifestasikan melalui novel Akar. Adanya keterkaitan antara cerita novel Akar yang berlatar belakang Buddhisme dengan ketertarikan Dee sebagai pengarang terhadap ajaran Buddha menjadi indikasi adanya relasi antara hasrat pengarang dengan novel Akar. Untuk menjawab indikasi tersebut penulis menggunakan metode Psikoanalisis Lacan yaitu melalui mekanisme metafora dan metonimi dengan menganalisis rangkaian penanda yang terdapat pada novel Akar sehingga ditemukan hasrat menjadi dan memiliki pengarang.
\end{abstract}

Kata kunci : Hasrat, Lacan, Akar, Dee, Metafora, Metonimi

Abstract

This research aims to describe how the author's desire manifested through Akar's novel. There was a relationship between the story of Akar's novel, which has a Buddhism background, with Dee's interest as the author's toward buddha's teachings that became an indication about the relation between author's desire and Akar's novel. To answer this indication, the writer used Lacan's Psychoanalysis method through the mechanism of metaphor and metonymy by analyzing a series of signifiers on Akar's novel, so it will discover what exactly the desire of "being" and "baving" of the author.

Keywords: Desire, Lacan, Akar, Dee, Metaphora, Metonymy

\section{Pendahuluan}

Akar adalah sebuah novel yang menceritakan perjalanan tokoh Aku yang bernama Bodhi dalam mencari kesejatian diri. Perjalanan ini dimulai ketika Bodhi memutuskan untuk keluar dari wihara, tempat dia hidup selama delapan belas tahun semenjak ia lahir, dengan tujuan terbebas dari siksaan yang dialami selama hidupnya. Dalam perjalanannya, Bodhi menginternalisasi beberapa identitas, salah satunya identitas sebagai bagian dari komunitas punk. Menjadi bagian dari komunitas tersebut, Bodhi menganggap perjalanannya untuk menemukan kesejatian telah berakhir. Namun kenyataannya, kegelisahan masih tetap dia rasakan dalam dirinya. Keadaan ini menunjukkan fakta bahwa kesejatian yang diinginkan oleh Bodhi belum didapatkannya. Puncak dari kegelisahan ini adalah ketika Bodbi berharap dimatikan dari kehidupan yang ia cintai tersebut. Sikap tersebut menunjukkan bahwa Bodhi masih saja merasakan kekurangan walaupun ia telah merasa bahagia di dalam hidupnya.

Dee menghadirkan cerita perjalanan mencari kesejatian diri dalam novel Akar yang dimana pencarian kesejatian diri oleh Bodhi adalah wujud dari kekurangan yang ingin dipenuhi tokoh tersebut. Kekurangan yang dirasakan oleh Bodhi merupakan representasi kekurangan yang dirasakan oleh Dee. Menghasilkan karya sastra adalah salah satu cara pengarang dalam memenuhi kekurangan yang ia rasakan, sehingga dapat dikatakan bahwa novel Akar adalah manifestasi dari hasrat Dee sebagai pengarangnya. Salah satu keyakinan utama dalam teori Lacan mengatakan ketidaksadaran merupakan struktur tersembunyi yang mirip dengan bahasa (Sarup, 2003:6), sehingga mengkaji karya sastra menggunakan teori Lacanian merupakan usaha untuk menemukan kondisi bawah sadar yang dipenuhi rasa kurang 
dan kehilangan.

Lacan mengatakan bahwa bahasa merupakan kondisi bagi ketidaksadaran, bahwa bahasa mencipta dan memunculkan ketidaksadaran itu (Faruk, 2012:188). Artinya bahasa adalah wujud dari ketidaksadaran itu sendiri, sehingga untuk mengetahui bagaimana hasrat pengarang terepresentasikan dalam karya sastra adalah dengan menganalisis bahasa yang dihadirkan dalam karyanya. Penelusuran hasrat yang tak disadari pengarang inilah yang menjadi tujuan dalam sebuah kajian psikoanalisis Lacanian. Ketidaksadaran terstruktur seperti bahasa yang mekanismenya bekerja melalui metafora dan metonimi, sehingga dengan menganalisis rangkaian kata (penanda dalam istilah Lacan) maka akan ditemukan apa hasrat menjadi dan memiliki pengarang.

Sarup (2003:9) mengatakan bahwa Lacan membangun teori bahasa yang lengkap, ia menghubungkan teori bahasanya dengan subjektivitas. Hal ini menunjukkan pengarang memiliki kecenderungan secara tidak sadar telah membawa permasalahan kejiwaan mereka ke dalam karya sastra yang dihasilkannya. Hal ini dapat dilihat dari cerita novel Akar yang berlatar belakang Buddhisme memiliki kesamaan dengan latar belakang Dee yang tertarik pada ajaran Buddha. Kesamaan tersebut menunjukan adanya relasi antara hasrat Bodhi pada novel Akar dengan hasrat Dee sebagai pengarang. Adanya hubungan antara religiusitas ajaran Buddhisme dengan pencarian kesejatian diri oleh Bodhi yang menjadi sajian utama pada novel ini membuat hasrat Dee sebagai pengarang menjadi menarik untuk diteliti.

Kebenaran dalam ajaran Buddhisme adalah kehampaan, di mana kehidupan haruslah dijalankan dengan hampa. Ketiadaan hasrat dalam menjalani kehidupan yang artinya kehidupan tidak berhubungan dengan pencapaian keinginan-keinginan, seperti yang dikatakan Zimmer (2003:470) bahwa Buddhisme adalah ajaran yang tidak berkaitan dengan realitas puncak. Jika melihat Bodhi pada novel Akar maka perjalanan yang ia lakukan adalah untuk mencapai kesejatian, yaitu kesejatian dalam ajaran Buddhisme. Bodhi menghasrati kesejatian yang dapat dicapai jika tidak menghasratinya, namun yang dilakukan oleh Bodhi adalah terus-menerus berhasrat pada kesejatian tersebut.

Hasrat adalah produk Yang Real yang bekerja pada tataran Simbolik. Hal ini menyebabkan, ketika hasrat akan kebutuhan Yang Real tidak dapat terpenuhi, manusia cenderung memanipulasi hasratnya dalam tataran Imajiner dan Simbolik (Lacan, 1974: vii). Hasrat pengarang yang bekerja pada tataran Simbolik dapat dilihat melalui fase cermin kedua yaitu, Oedipus Complex dan bahasa. Melalui pengidentifikasian dan pemaknaan rangkaian penanda menggunakan perspektif Lacanian maka dapat diketahui bagaimana hasrat menjadi dan memiliki pengarang termanifestasi pada novel Akar.

\section{Citraan "Liyan" sebagai Cermin Tokoh "Aku"}

Hasrat pada dasarnya adalah keinginan akan kepemilikian identitas, di mana identitas tersebut diperoleh melalui proses identifikasi melalui citraan, penanda utama, dan fantasi. Dalam tataran imajiner, subjek mengangap liyan adalah cermin dari 'aku', akan tetapi, Liyan bukanlah "aku" namun liyan menjadi "aku". Lacan menekankan poin bahwa tidak ada subjek kecuali dalam representasi, dan bahwa tidak ada representasi yang dapat merangkum diri kita secara utuh. "Saya tidak dapat didefinisikan secara utuh dan saya juga tidak dapat melepaskan diri dari semua definisi yang ada" (Sarup, 2003:14-15). Hal ini menunjukkan bahwa cara liyan memandang diri subjek berpengaruh pada bagaimana subjek memandang dirinya sesuai dengan konsep dialektika pengakuan yang juga bagian dari pemikiran Lacan. Dengan demikian, citraan liyan yang menjadi cermin Bodhi akan berpengaruh pada hasrat yang dimiliki Bodhi. Bodhi diceritakan telah memilih identitas sebagai anak punk, namun identitas yang melekat pada Bodhi sekarang adalah gabungan dari beberapa identitas yang telah ia dapatkan dari lingkungan sebelumnya yaitu lingkungan wihara, lingkungan backpacker, lingkungan pentato dan lingkungan komunitas punk.

Identitas pertama ia dapatkan dari kehidupan wihara. Selama di wihara, Bodhi 
tinggal bersama Guru Liong yang merupakan citra pertama dan satu-satunya yang ditangkap oleh Bodhi selama belasan tahun. Hal ini menyebabkan citraan awal yang ditangkap oleh Bodhi sebagai pembentuk ego adalah citraan guru Liong. Guru Liong adalah seorang biksu yang mengajari Bodhi semua mengenai kebuddhaan, mempengaruhi cara Bodhi menjalani kehidupannya.

\section{"Delapan belas tahun. Aku belajar hampir segalanya} di Wihara Pit Yong Kiong, daerah Lawang, 60-an kilometer dari Surabaya ke arah selatan. Mulai dari merangkak, bicara, sampai pipis sendiri. Aku hafal ratusan mantra bahasa Mandarin-termasuk dialek Hok Kian dan Kanton-juga bahasa Pali. Tidak pernah kuanggap itu unik. Wihara memang hidupku. Tak ada piliban lain" (Dee, 2002: 38).

Penanda delapan belas tahun di wihara secara metaforik berhubungan dengan "aku hafal ratusan mantra dan wihara adalah bidupku". Secara metonimik, penanda ini menggantikan citra ideal seorang biksu. Penanda tak ada pilihan lain menunjukan bahwa si Aku mengakui kekuasaan dunia "Yang Simbolik" yaitu sebuah area terdapat konsep "the name of father".

Dalam psikoanalisis Lacan, the name of father (hukum sang ayah) adalah tataran norma dan aturan-aturan yang mengikat dalam suatu masyarakat yang telah menjadi konvensi. Norma dan aturan inilah yang membuat Bodhi mengikuti konvensi dalam kehidupan di dalam wihara tersebut. Berdasarkan kutipan di atas, Bodhi menyadari dirinya ditanami identitas oleh liyan yang dapat dilihat dari penanda "tak ada piliban lain". Akan tetapi di sisi lain, Bodbi menyakini dirinya adalah subjek atas identitas yang melekat padanya melalui penanda "wihara memang bidupku". Pernyataan ini terhubung dengan konsep Lacan yang mengatakan, "kita tidak pernah dapat yakin pada tanggapan orang lain, kita memang memiliki pandangan tentang identitas kita, tapi pandangan tersebut tidak berkaitan dengan realitas: citra cermin kembali diajukan" (Sarup, 2003:14).

Saya adalah proses pencarian menuju diri yang sejati (Sarup, 2003: 15-16) yang mengisyaratkan bahwa pencarian identitas akan berlangsung terus-menerus, dan inilah yang dilakukan Bodhi dengan memutuskan keluar dari wihara dan memulai perjalanannya. Awalnya, Bodhi tidak memiliki penanda identitas sebagai seorang backpacker. Akan tetapi, pertemuannya dengan Tristan membuat subjek menginternalisasi penanda-penanda backpacker pada dirinya, sehingga Bodhi pun terikat dengan aturan-aturan (the name of father) dalam dunia backpacker.

"Dari sebulan pertama, aku berbasil mengumpulkan uang untuk beli satu ransel bekas di pasar Pahurat, satu sleeping bag yang juga bekas, dan tinggal bersama orang lain di sebuab kamar mungil, di sebelah timur area Banglamphoo, dengan tarif 40 baht per malam" (Dee, 2002: ).

Penanda ransel, sleeping bag, dan tinggal bersama di kamar mungil merupakan penanda yang identik dengan komunitas backpacker. Bodhi yang awalnya tidak mengandung penanda seorang bacpacker pada dirinya, dalam ketidaksadarannya telah menginternalisasi citraan dari liyan yang seorang backpacker sebagai identitasnya. Identitas backpacker merupakan gerbang pembuka yang akan mengantarkan Bodhi melakukan perjalanan mencari kesejatian diri. Perjalanan ini mempertemukannya dengan sosok Kell yang merupakan seorang seniman tato. Bodhi menghasrati identitas Kell, sehingga ia berharap bisa sebaik Kell atau bahkan lebih baik dari Kell dalam hal mentato. Hal tersebut tampak dalam kutipan berikut, 'I'd give you an 8.5 for this one. Gambarmu babkan sudab lebih baik dari saya."(Dee, 2002; 109).

Menghasrati identitas orang lain sebenarnya adalah hasrat pada "pengakuan". Bodhi-pun pada akhirnya diakui oleh Kell pada detik-detik kematiannya dengan mengizinkan Bodhi merajahkan tato ke tubuhnya. Semenjak itu, Bodhi berprofesi sebagai seniman tato. Kematian Kell membawa Bodhi kembali ke Indonesia dan bertemu dengan Bong, seorang punk. Bodhi mengagumi Bong dengan pemikiran, pilihan hidup, dan keahlian yang ia miliki. Bagi Bodhi komunitas punk adalah rumahnya yang memberikan isyarat bahwa menjadi bagian dari komunitas punk artinya meraih kesejatian yang 
ia inginkan, hal ini tercermin melalui kutipan berikut "pada saat itulah kutemukan rumah yang kucari-cari" (Dee, 2002: 29).

Bodhi telah menginternalisasi beberapa identitas ke dalam dirinya selama melakukan perjalanan yaitu identitas biksu, backpacker, seniman tato, dan terakhir punk. Identitasidentitas tersebut didapatkan Bodhi dari liyan, dimana Liyan adalah bukan 'aku' tetapi sekaligus diakui sebagai 'aku'. Pada akhirnya, hasrat yang dimiliki oleh Bodhi berasal dari cermin yang dipantulkan Liyan (Guru Liong, Tristan, Kell, dan Bong), yang merupakan cermin hasrat Bodhi yang secara metaforik diibaratkan sebagai hasrat biksu, backpacker dan seniman tato serta punk.

Identitas selalu berkaitan dengan citra cermin, yakni kemunculan hasrat subjek berasal dari cermin yang dipantulkan liyan. Citra cermin adalah metafor yang bekerja ke dalam dan ke luar, ketika liyan menanamkan citranya, pada saat itu posisi liyan adalah subjek namun sekaligus juga sebagai objek dari hasrat biksu lain, backpacker lain, seniman tato lain, atau anak punk lain atau bisa juga hasrat pengarang. Lacan mengatakan semua hasrat adalah hasrat pada nilai (Sarup, 2003:24), dengan kata lain, yang dihasrati pengarang melalui Bodhi adalah nilai yang ada pada identitas biksu, backpacker, penato, dan seseorang yang menganut aliran punk. Keadaan ini secara metonimik, hasrat Bodhi dapat mengantikan hasrat pengarang, yaitu Dee.

Dee menyatakan bahwa kehidupan nyata juga merupakan tema pembangun dalam setiap cerita yang ia buat sehingga dapat dikatakan hasrat Bodhi pada novel Akar adalah hasrat dari Dee sebagai pengarang. Jika pada novel Akar, Bodhi memutuskan untuk meninggalkan wihara dengan tujuan untuk menemukan kesejatian, maka Dee memutuskan untuk melakukan pencarian kepercayaan yang benar-benar ia yakini dengan meninggalkan kepercayaan yang diwariskan oleh orang tuanya. Pada tahun 2002 yang merupakan tahun lahirnya novel Akar, Dee menyatakan pengakuannya akan rasa jatuh cinta pada Buddhisme.

\section{Perjalanan : Kerinduan pada Yang Real}

"Ini kisah perjalanan menemukan diri, yang di ujung ceritanya nanti, perjalanan itu pun masib belum selesai." (Dee, 2002: 37). Kutipan tersebut menunjukan pencarian kesejatian diri adalah perjalanan yang terus berlangsung. $\mathrm{Hal}$ ini berkaitan dengan pendapat Lacan yang mengatakan bahwa saya adalah proses pencarian menuju diri yang sejati (Sarup, 2003:15). Bodhi adalah metafora dalam perjalanan itu sendiri, identitas-identitas yang telah ia internalisasi, nyatanya belum dapat membuat $\underline{B o d h i}$ merasakan keutuhan di dalam dirinya. Oleh karena itu, Bodhi masih terus melakukan pencarian jati diri. Perjalanan untuk mencari kesejatian tersebut adalah wujud dari upaya pemenuhan lackness yang ia rasakan. Pandangan Dee sebagai pengarang mengenai perjalanan untuk menemukan kesejatian diri termanifestasi pada novel Akar melalui kehadiran dan sudut pandang para tokoh, salah satunya yaitu tokoh Luca.

"Sebentar dulu," susah benar bicara, tetapi kucoba terus, "buat apa mereka capek-capek keluar kalau memang nanti-nantinya kembali lagi? Tinggal saja terus di Firdaus. Beres. Gitu saja, kok, repot."

"So there can be a jorney, you fool," Luca balas memotong gemas. "Satu-satunya cara mengetahui asalusulmu adalah keluar, lalu kembali. Kamu pikir si Adam itu tabu dirinya istmewa kalau tidak dibuang dulu ke bumi?"(Dee, 2002: 156-157).

Penanda keluar lalu kembali pada kutipan tersebut adalah metafora dari perjalanan. Perjalanan yang dilakukan untuk menemukan asal-usul dan keistimewaan diri yang secara metonimik dapat menjadi pengganti dari kesejatian. Percakapan antara Luca dan Bodhi menyiratkan sudut pandang Dee mengenai kebutuhan akan akivitas perjalanan untuk memperoleh kesejatian. Kutipan tersebut memperlihatkan betapa pentingnya sebuah perjalanan, karena perjalanan adalah jalan menuju kesejatian itu sendiri. Kesejatian yang dihasrati pengarang melalui Bodhi.

Perjalanan yang dilakukan Bodhi menghadirkan identitas-identitas yang 
diinternalisasi ke dalam dirinya. Identitas biksu yang dimiliki oleh Bodhi menunjukkan kesejatian seperti apa yang menjadi obsesinya. Hal ini tercermin melalui kutipan berikut:

"Sambil berjalan Aku pun berpikir, dapatkah Bodhi, yang hanya berjalan kaki ini beroleh nirwana yang sama? Dan, apakah mereka, yang telah mendedikasikan selurub hidupnya untuk menghias Buddha, telah beroleh nirwana itu?" (Dee, 2002: 122).

Penanda nirwana yang terdapat pada kutipan tersebut adalah ruang kesejatian yang diinginkan Bodhi. Hal ini dikarenakan citraan yang telah ditanamkan oleh Guru Liong pada dirinya sehingga memunculkan hasrat pada dirinya akan kesejatian dalam ajaran Buddha.

Identitas backpacker yang membuat Bodhi terus berjalan dan tidak berhenti di satu titik serupa dengan perjalanan spirit Gautama yang merupakan tokoh penting dalam agama Buddha yang juga melakukan perjalanan guna mencapai kesejatiannya. Kemudian identitas penato, dimana dengan keahlian menatonya Bodhi membebaskan Kell dari penderitaan. Hal tersebut jika dihubungkan dengan agama Buddha seperti seorang pencerah yang membebaskan orang lain dari nerakanya. Serupa dengan seorang juru selamat (Bodhisattva) dan itulah yang dilakukan Bodbi pada Kell melalui identitas penatonya.

Identitas-identitas tersebut memberikan fantasi atas kemerdekaan diri yang dimulai dari keluarnya Bodhi dari wihara sampai akhirnya menjadi bagian dari komunitas punk. Akan tetapi, kebebasan sejatinya adalah bentukan bahasa yang hanya memberikan fantasi atas kepenuhan diri. Bodbi berharap perjalanan yang ia lakukan dapat mengembalikannya pada Yang Real dimana ia dapat memilih apa yang ia inginkan.

Perjalanan sendiri adalah metafor dari kerinduan Bodbi pada keutuhan. Perjalanan membuat Bodhi bebas untuk memilih identitas yang ia kehendaki. Kebebasan adalah hasrat kembali pada Yang Real, akan tetapi yang simbolik selalu berhasil mengilusi subjek agar seolah-olah utuh. Bodhi memang memilih sendiri identitas yang akan diinternalisasi sesuai dengan keinginannya. Tetapi di sisi lain identitas-identitas yang melekat pada dirinya tersebut adalah identitas yang didapatkannya karena telah mematuhi aturan-aturan dunia simbolik.

\section{Kesejatian sebagai Permintaan (demand)}

Permintaan menurut Lacan adalah sesuatu yang tidak dapat atau tidak mungkin terpenuhi. Hal ini tampak dalam perjalanan yang dilakukan Bodhi untuk menemukan kesejatian. Walaupun dalam perjalanan tersebut Bodhi telah menginternalisasi identitas biksu, backpacker, seniman tato, dan punk namun Bodhi tetap merasakan kekurangan. Hal ini mengisyaratkan bahwa kesejatian yang diinginkan Bodhi adalah sesuatu yang tidak akan pernah tercapai. Artinya kesejatian adalah objek permintaan bagi subjek yang mana permintaan adalah sesuatu yang tidak dapat atau mungkin untuk dicapai. Hal ini tercermin pada kutipan berikut:

'U2 benar. I still haven't found what I'm looking for. Aku tak tabu apa yang kucari, tak tabu berapa lama dan seberapa lama lagi" (Dee, 2002: 21).

Penanda "I still haven't found what I'm looking for" dan "Aku tak tahu apa yang kucari" merupakan metafora dari kesejatian. Kedua penanda tersebut menunjukkan objek permintaan subjek. Objek permintaan berupa kesejatian yang tidak diketahui oleh subjek bagaimana bentuknya. Ketidaktahuan ini yang menyebabkan subjek terus mencaridan berujung pada tidak terpenuhinya permintaan subjek akan kesejatian diri. Lalu seperti apa bentuk dari kesejatian yang diinginkan Bodhi tersebut? Kesejatian yang ingin dicapai oleh Bodhi adalah kesejatian yang berhubungan dengan ajaran Buddha yaitu sebagai Bodhisattva. Bodhisattva adalah metafora dari kesempurnaan yang artinya kerinduan subjek pada fase real. Fase real adalah fase dimana subjek dapat merasakan keutuhan, namun fase tersebut hanya terjadi ketika bayi dan tidak akan pernah terulang kembali. Maka dari itu kesejatian yang diinginkan Bodhi akan tetap menjadi permintaan yang tidak dapat dicapai dan tidak akan pernah terpenuhi. 


\section{Kematian: Kegelisahan Hilangnya Objek $a$}

Sejak manusia lahir, ia dibekali oleh dua naluri dasar dalam lapisan psikis paling dalam yaitu eros (naluri kehidupan) dan thanatos (naluri kematian). Kedua naluri ini tergambar pada novel Akar yaitu mengenai pencarian kesejatian (kehidupan) dan kematian. Kesejatian diri adalah sesuatu yang akan terus-menerus diinginkan oleh diri oleh karena itu kesejatian diri akan terus menjadi permintaan bagi manusia. Akan tetapi, kesejatian diri inilah yang memunculkan hasrat-hasrat manusia untuk keberlangsungan hidupnya. Manusia adalah subjek, sedangkan kesejatian diri dan kematian adalah objek, menurut Lacan objek adalah sesuatu yang hilang.

Pada novel Akar, pengarang menghadirkan Liyan Simbolik (tokoh Liong, Kell, dan Bong) bagi Bodhi karena mengakui dan mencintai keberadaraan diri dari Bodbi. Keberadaan liyan dibutuhkan oleh Bodhi untuk menjaga eksistensi diri. Subjek ada karena adanya objek. Dalam novel Akar diceritakan bahwa tokoh Liong dan tokoh Kell pada akhirnya meninggal sehingga sosok liyan yang mengakui eksistensi Bodbi hanya tinggal Bong saja. Kehilangan Liong dan Kell sebagai Liyan Simbolik membuat eksistensi Bodhi menjadi tidak berarti oleh karena itu Bodhi berharap segera dimatikan oleh alam beserta isinya.

Kematian yang diinginkan oleh Bodhi pada novel Akar ini adalah metafora dari kehidupan adalah penderitaan, hal tersebut tampak pada kutipan berikut;

"Aku ingin si "Bodhi" mati. Siapa pun itu sesunggubnya. Karena bidup ini telalu sakit. Capek. Mau muntah. BLAH! PUAH! Hrrrgkh.... (Dee, 2002: 24).

Kutipan tersebut menunjukkan bahwa kematian yang diinginkan oleh Bodhi bertujuan untuk menghentikan penderitaannya. Hal ini berelasi dengan pencapaian nirwana dalam ajaran Buddha. Nirwana adalah ruang tepi kearifan bagi orang yang tercerahkan dimana penderitaan tidak lagi dirasakan. Tidak ada lagi kelahiran kembali, dan Bodhi ingin mencapai nirwana dengan kematiannya. Kematian adalah metafora akan suatu tahap di mana seseorang dapat memperoleh nirwana. Kematian yang dimaksud bukanlah makna kematian yang menyebabkan jasad seseorang menjadi bangkai, tetapi makna bahwa kematian adalah sebuah kemerduan yang mempertemukannya pada kesejatian. Citraan bahwa nirwana adalah ruang di mana orang yang mendapatkan pencerahan absolut berada. Hal ini menyebabkan Dee menghasrati kematian. Nirwana merupakan tempat bagi Bodhisattva. Keinginan atas identitas Bodhisattva adalah wujud dari kerinduan subjek atas fase the real.

Bodhi mengira bahwa dengan kematian, subjek dapat merasakan keutuhan, padahal hal tersebut hanya fantasi belaka. Bodhi telah kehilangan objek hasratnya yaitu objek $a$-nya sehingga hadirlah keinginan akan kematian yang merupakan wujud dari kegelisahan. Objek a yang dimaksud adalah kesejatian diri yang diinginkan Bodhi. Ketika ketidaksadaran mencuat maka naluri akan kematian menguat dalam diri manusia. Dalam ajaran Buddha, seseorang yang mengandung eksistensi tidak akan pernah pendapatkan pencerahan. Bodhi adalah sosok yang mengandung eksistensi maka dari itu ia menginginkan kematian untuk menghilangkan eksistensinya untuk mencapai kesejatian. Kematian yang diharapkan Bodhi juga berelasi dengan kepercayaan Lacan bahwa kehidupan adalah penyakit dan penyembuhannya adalah kematian. Lacan memahami kematian sebagai "Tuan Absolut". Bagi Lacan, hasrat bersifat tidak terbatas, dan hanya kematian yang menjadi batas hasrat.

\section{Hasrat Menjadi (Narsistik)}

Hasrat menjadi adalah hasrat yang memanifestasikan dirinya dalam bentuk cinta dan identifikasi yang bekerja pada ranah pengalaman yang nyata, praideologis, dan non makna. Ia adalah potensi resistensi yang selalu menganjal hasrat untuk memiliki dalam menunaikan hajatnya (Adian, 2009: xiiii). Kesejatian yang dinginkan Bodhi merupakan kesejatian dalam ajaran Buddhisme, yaitu kesejatian seperti seorang Bodhisattva. Hal ini bukan berati pengarang menginginkan menjadi seorang Bodhisattva sebagai identitasnya. Akan 
tetapi, yang ingin dicapai adalah kesempurnaan dari seorang Bodhisattva yang merupakan kerinduan subjek pada fase real.

Kesempurnaan tersebut merupakan hasrat yang timbul atas apa yang terjadi di kehidupan nyata Dee di masa lalu. Dee menyadari agama yang dianutnya adalah warisan dari orang tuanya dan identitas tersebut bukanlah identitas yang ia pilih sendiri. Kekurangan yang Dee rasakan membuatnya mengambil keputusan untuk meninggalkan identitas yang telah diberikan kepadanya dan mulai melakukan pecarian akan dirinya. Hal ini menunjukkan bahwa Dee mencoba mencari kesempurnaan (keutuhan) pada identitas yang lain atas kekurangan yang ia rasa pada identitas yang sebelumnya melekat padanya.

Tanpa menggenggam 'mati' suatu keyakinan, Dee memulai pencarian realitas tertinggi, mempelajari berbagai ajaran agama dengan tanpa prasangka, dan tanpa membanding-bandingkan. Dee mulai mempelajari semua agama untuk membuktikan sendiri, yang pada akhirnya ia yakini untuk menjadi bagian dari identitasnya.

\section{Hasrat Memiliki (Anaklitik)}

Hasrat memiliki (anaklitik) adalah hasrat memiliki Liyan (materi, benda, orang, posisi, dan kekuasaan) sebagai cara untuk memuaskan diri. Hasrat memiliki bekerja pada ranah pengalaman Imajiner dan Simbolik yaitu ranah pengalaman yang memberi keutuhan pada kekurangan primordial yang selalu membayangi subjek. Ia mengambil bentuk pada cara mendapatkan kesenangan yang bertentangan dengan diri dan orang lain. (Adian, 2009: xiiii). Subjek yang berkekurangan selalu berupaya untuk memenuhi kekurangan yang ia rasakan. Subjek mencari objek a agar dirinya dapat merasakan kesempurnaan.

Ketigaidentitas yang telah diinternalisasi, terutama identitas punk, membuat Bodhi seolah-olah mendapatkan kesempurnaannya sebab ketiga identitas tersebut tanpa disadari mengarahkan Bodhi pada kesejatian yang ingin ia capai yaitu kesejatian berbentuk Bodhisattva. Ketiga identitas tersebut mengarahkan ia pada kesejatian yang dihasrati oleh liyan sekaligus dirinya. Kesejatian inilah yang menjadi objek a bagi Bodhi. Akan tetapi, kesejatian yang merupakan metafora dari kesempurnaan ini adalah sesuatu yang tidak akan pernah subjek capai.

Jika dicermati identitas backpacker, penato, dan punk yang telah diinternalisasi Bodhi adalah identitas yang masuk ke dalam area minor dalam masyarakat Indonesia. Hal ini adalah bentuk dari hasrat Dee pada identitas yang autentik. Dee melalui Bodhi menghasrati nilainilai dibalik identitas penato, backpacker, dan punk. Dee dalam karyanya menjabarkan sudut pandang yang berbeda atas budaya minoritas tersebut. Budaya yang dianggap minoritas dan cenderung bercitra negatif bagi masyarakat Indonesia justru dipilih Bodhi sebagai bagian dari identitasnya. Pemilihan identitas yang masuk ke area minor tersebut menunjukkan bahwa Dee adalah adalah individu yang bebas. Tidak peduli dengan konvensi stigma negatif masyarakat untuk menentukan identitas yang diiinginkannya. Hasrat akan identitas yang autentik yang yang tertuang pada novel Akar karya Dee, merupakan metafora akan kebebasan dalam beridentitas. Kebebasan yang dimaksud mengandung arti bahwa identitas adalah sesuatu yang didapatkan melalui sebuah perjalanan bukan hanya sekedar menerima kontruksi dari Liyan.

\section{Kesimpulan}

Melalui metode psikoanalisis Lacanian dan mekanismenya maka penelitian ini menghasilkan beberapa kesimpulan. Pertama, novel Akar adalah metafora dari kehidupan Dee ketika ia mengalami fase pencerahan dalam hidupnya. Dee mengalami fase pencerahan di dalam hidupnya. Tanpa menggenggam 'mati' suatu keyakinan, Dee memulai pencarian realitas tertinggi. Mempelajari berbagai ajaran agama dengan tanpa prasangka dan tanpa membanding-bandingkan. Novel Akar adalah metafora dan metonimi dari pencarian Dee akan kesejatiannya.

Kedua, dalam psikoanalisis Lacan, terdapat dua bentuk hasrat yaitu hasrat menjadi (narsistik) dan hasrat memiliki (anaklitik). Hasrat menjadi (narsistik desire) pada novel Akar 
adalah mengenai kesejatian dan perjalanan menemukan kesejatian tersebut. Penanda 'kesejatian' yang ada pada novel Akar adalah metafora dari kesempurnaan yang diinginkan oleh Dee, sedangkan penanda 'perjalanan dalam menemukan kesejatian' adalah metafora dari kebebasan yang diinginkan Dee dalam mencapai identitas yang diinginkannya. Kesejatian diri yang didapatkan melalui perjalanan adalah pencarian yang dilakukan dengan mempelajari dan membuktikan sendiri.

Hasrat memiliki (anaklitik desire) pada novel Akar adalah Dee sebagai subjek yang berkekurangan mencari keutuhan dengan berusaha memiliki objek a, yang dalam hal ini Dee ingin memiliki kesejatian sebagai metafora akan kesempurnaan diri. Dengan memiliki kesejatian, Dee berharap akan menemukan apa yang hilang dan kurang dalam dirinya sehingga pada akhirnya ia dapat merasakan kesempurnaan diri. Namun, kesejatian yang merupakan metafora dari kesempurnaan ini adalah sesuatu yang tidak akan pernah subjek capai. Kesejatian adalah kerinduan subjek pada fase real dimana subjek pernah merasakan keutuhan. Dengan demikian, kesejatian dan perjalanan menemukan kesejatian diri yang dihadirkan Dee pada novel Akar melalui tokoh Bodhi adalah wujud dari hasrat Dee akan memiliki kesempurnaan dan kebebasan dalam menentukan identitasnya untuk menjadi manusia yang sempurna.

\section{Daftar Pustaka}

Adian, Donny Gahral. 2009. Pesona Hasrat dalam Psikoanalisis-Struktural Jaques-

Lacan: Refleksi atas ketegangan antara Hasrat Memiliki dan Hasrat Menjadi. Diskursus dan Perubahan Sosial: Pengantar Kritik Budaya Psikoanalisis. Yogyakarta: Jalasutra.

Faruk. 2012. Metode Penelitian Sastra: Sebuah Penjelajahan Awal. Yogyakarta: Pustaka Pelajar.

Lacan, Jacques. 1977. Ecrits: A Selection, terj. Alan Sheridan. London. Tavistock.

Lestari, Dee. 2012. Akar. Yogyakarta: Bentang Pustaka.

Sarup, Madan. 1993. Postrukturalisme dan Posmodernisme, Sebuah Pengantar Kritis. Terjemahan Medhy Aginta Hidayat. 2003. Yogyakarta: Jendela.

Zimmer, Heinrich. 2003. Sejarah Filsafat India. Pustaka pelajar: Yogyakarta. 